The Japanese Journal of Experimental

Social Psychology. 1989, Vol. 28, No. 2, 105-113

〔原

著]

\title{
援助要請の原因帰属と親密性が 援助行動に及ぼす効果
}

大阪教育大学

西川正之

\section{問}

\section{題}

援助を求められた人が援助するか否かの判断を下すと き, 多くの場合, 相手が助けを必要とするようになった 理由の推測が, 重要な規定因になる。Meyer \& Mulherin (1980) が述べるように, 従来の援助行動の原因帰属 に関する研究では, 援助者の行動が Weiner ら (1979) の「動機の原因帰属モデル」によって説明されてきた。 つまり人は, 自分自身や他者が達成課題に成功したり失 敗したりするのはなぜかと考え，その原因をどてに州属 させるかによって, その人の満足感や将来の成功の見込 み, および次の課題への対処行動などが異なってくると いう。Weiner は，また，彼の初期の研究 (1972) にお いて, 成功・失敗の主たる原因が，内的原因か外的原因 かといった「原因の位置」の次元と，安定した原因か不 安定な原因かといった「安定性」の次元とによって分類 できると考えている。その後, Weinerの 2 次元に加え て, Rosenbaum (1973) は, 第 3 の次元として「意図 性」を提案したが，ての次元はさらに概念化され，今日 では自分自身で統制できる原因か統制できない原因かと いう「統制可能性」の次元 (Weiner, 1979) とされてい る。

Weiner (1979) は, 行動が多くの感情反応から生みだ され，しかもその感情反応が以上の 3 つの因果的特性次 元によって規定されると論じた。最終的には，ての3つ の原因特性が達成行動に影響を及ぼすとしているが，乙 の影響は, 感情と将来同じ結果が生まれる見込みとによ って媒介されると予想している。例えば，成功・失敗の 後に将来の達成行動について抱く信念は, 第 1 亿原因の 安定性によって影響されると考え，その影響過程を次の ように説明している。人は成功・失敗の原因を安定した 要因に帰属すると, 不安定な要因に帰属する時よりあ, 将来同じ結果の生まれる確率（可能性）が高いと推測す る。そして, 将来成功する見込みが高いとか, 好ましい
関西大学

高木修

感情が生じるといった原因帚属は, 否定的な感情や低い 成功の見込みを生みだす原因帰属よりも, 人を将来同じ ような結果を生みだしやすい達成課題に喜んで取り組ま せる。

最近, Weiner のモデルを愛他的行動の説明に用いる 試みが, 幾つかの研究で行われている。Ickes \& Kidd (1976) は, Weiner の考え方が援助行動の原因帰属的分 析をすすめる上で非常に有効であると述べている。援助 行動に帰属論的アプローチを試みた初期の研究は, 人 が, 援助を求めるに至った原因を, 援助要請者自身（す なわちその人の内的原因）に帰属するのではなく，その 人を取りまく環境（外的原因）に帰属するときに, いっ そう進んで援助の手を差し延べることを明らかにした (Berkowitz, 1969; Schopler \& Matthews, 1965)。し かし Ickes \& Kidd (1976) は, 初期の幾つかの研究が Weiner モデルの「統制可能性」次元と「原因の位置」 次元を混同していると指摘した。例えば，Berkowitz の研究では, 援助要者自身の原因が, 内的であると同時 に, 統制可能な原因であり, 他方, 環境的原因は外的で あり, また統制不可能な要素を含んでいた。Ickes \& Kidd (1976) は, 援助を必要とする状況が, 要請者自身 の内的で, かつ統制可能な要因によって引き起てされた ときに, 最も援助されにくく, 他方, 外的で, 統制不可 能な原因に帰属されるときに, 最も頻繁に援助が提供さ れることを明らかにした。さらに Ickes らは，原因の位 置次元よりも, 統制可能性次元のほうが, 援助するか否 かの判断過程に，より重要な影響をおよぼすと述べてい る。例えば, Piliavin ら (1969) が地下鉄内で行った実 験では, 酔っぱらって床に倒れた人よりも, 病気で倒れ た人への援助が多く現われた。乙の結果は, 援助を求め る原因が内的であっても，それが統制できる要因よりあ 統制できない要因に帰属される場合に, 援助の手が差し 延べられやすいてとを示している。Weiner (1980) は, 人が援助を申し出るか否かの判断が, ほとんど, 援助要 
請原因の「原因の位置」と「統制可能性」との交互作用 効果によって説明されるてとを見出した。すなわち，講 義ノートをとれたのに，あえてとらなかった学生に，喜 んでノートを貸す人は，あまりいなかった。Barnesら （1979）もまた，努力不足によって困った状況に陷った （内的で, 統制可能な原因に帰属される）学生に対して, 人はあまり進んでノートを貸さないてとを明らかにして いる。乙れらの結果は, Ickes らの指摘を支持している と考える。

Meyer ら (1980) は，援助行動研究に対するWeiner のモデルの適用を, つまり帰属の 3 次元が感情反応や将 来の見込みを規定し，その感情や見込みが，次に，援助 の決定に影響を及ぼすという考え方をさらに詳細に検討 した。彼らは，援助を必要とするようになった原因が， 助けを求める人の内的で統制可能な要因に帰属される時, 被要請者の要請者に対する怒りが強まり, 他方, 外的で 統制不可能な要因に帰属される時, 共感的感情か強まる と考えた。安定性に関しては, 援助要請が安定した原因 に帰属される時, 不安定な原因に帰属される時よりも, 将来その要請者が再び援助を求める機会が多いと推測す ると仮説した。そして，援助を求める人への共感的感情 が強ければ強いほど，また，今後その人が同じような援 助を求めてくる見込みが低ければ低いほど，援助を求め られた者は一層こころよく, その要請に応じると予想し た。

しかしながら, Meyer らの調查は, Weiner のモデル を, 完全に確証したわけではなかった。つまり, 安定性 之将来その人が同じような援助を求める見込みとの間に はあまり強い相関関係がなく，また将来の見込みが援助 行為をさほじ強く規定しなかったのである。 Meyer ら は, 乙の結果について, 第 1 亿, 安定性の効果があっと 強くはたらくように操作していれば，あるいは将来の見 込みとして, 援助要請とは違ったタイプの行動の見込み が測定されていたならば，あっとはっきりとモデルの有 効性が立証されたであろうと考察している。また小嶋 （1983）は，原因帰属が感情を媒介にして援助判断に影 響を及ぼすてとを明らかにしたが，因果次元を統制可能 性に限定しており, 因果 3 次元と援助行動の関係を検証 してはいない。そてで本研究では, 今一度, 援助行動に 対するWeiner モデルの適用可能性を検証する。

ところで, Meyer らの研究では, 援助要請者之被要 請者との関係性が，「知人」とされていたが，二者間の 親密さの程度は, 被要請者の感情反応, 将来の援助要請 の見込み，およびそれらを通じて援助可能性に影響を及 ぼすと考えられる(小嶋, 1983)。つまり，両者が親密な
関係にある場合，将来再度援助を求めてくる可能性は高 いと予想されるが，しかし，2 人が親しい間柄であるゆ えに, 援助を要請されても要請者への怒りは生じにくく, 逆に，共感的感情が喚起されやすいだろう。このような 場合, 親密な関係における将来の援助再要請の高い見込 みは援助可能性に対して抑制的に㗢くが，Meyer らが 指摘したように, その影響は被要請者の感情反応の効果 ほど強くなく, 弱い否定的感情と強い肯定的感情の方が, 援助の可能性に一層影響し，それを高めるだろう。

以上の議論をふまえて, 本研究では次の仮説の検証を 試みる。

仮説 1 援助要請に伴う感情は, 要請理由の原因㷌属 によって異なる。（a）援助要請原因が内的であ る時, 統制可能な原因に帰属される時，あるい は将来の援助要請の見込みが大きい時, 否定的 感情は一層強い。逆に，(b) 援助要請理由が外 的である時, 統制不可能な原因に帰属される時, あるいは将来の援助要請の見込みが小さい時, 肯定的感情は一層強い。

仮説 2 将来同じ人から再び援助を要請されると思う 見込みは，要請理由の原因帰属によって異なる。 援助要請が安定した原因に帰属される時, 再要 請の見込みは大きい。

仮説 3 援助の可能性は, 援助要請者に対する感情之 将来の再要請の見込みとによって異なる。

(a) 否定的感情が弱いほど, (b) 肯定的感情が 強いほど, あるいは (c) 将来の再要請の見込み が小さいほど, 援助の可能性は高い。

仮説 4 援助要請者と被要請者との関係の質によって, 要請に伴う感情, 将来の再要請の見込み, およ び援助可能性は異なる。両者の関係が親密であ ると, (a) 弱い否定的感情之, (b) 強い肯定 的感情のために, 援助可能性は大いに高まり, 他方，(c) 将来の再要請の見込みが高く，それ によって援助可能性は低まるが, 全体としては (d) 援助可能性は高い。

$$
\text { 方法 }
$$

被験者 K大学の学部学生204人（男子 132 人, 女子72 人）が被験者としてての調查に参加した。

手続き 被験者に，ある場面の叙述とその内容につい ての質問を印刷した調查用紙を配布した。そして, 場面 をよく読んで, 質問に答えるように教示した。

場面の設定「教授から，ある日の授業についてのレ ポートを提出するように求められました。そのレポート 
は，単位を修得するために必ず提出しなりればなりませ ん。あなたは既にそのレポードを書き上げています」と して，仮想場面を設定した。

变数の操作 高親密性条件の被験者洒配られた冊子で は，「あなたは非常に親しい友人Aさんから，その日の 授業を休んだので，レポートを見せて欲しいと頼まれま した」と述べられた。他方, 低親密性条件の被験者に対 する冊子では，「1，2 度しか言葉を交わしたてとのな い知人Aさんから……と述べられた。

帰属の次元む, Meyer ら (1980) の場面設定の方式に 従い, 場面の内容を変化させることで操作した。先ず, 不安定条件では,「Aさんはいつもまじめに授業に出席 している」とし, 安定条件では, 「普段からさぼりがち である」と設定した。つぎに，内的条件では，「その日 の授業を, 友人と遊びに行くために, 欠席した」とし, 外的条件では, 「親戚の法事のために, 欠席した」之設 定した。さらに, 統制可能条件では, 「自力でレポート を書けたが, 面倒なのであなたに見せて欲しいと頼ん だ」とし, 統制不可能条件では，「書こうとしたが，よ く分からなかったので，あなたに見せて欲しいと頼ん だ」と設定した。

質問項目 援助を要請された人が援助要請者に対し て経験する感情を捉えるために, Meyer \& Mulherin （1980）が用いた質問項目を参考にしつつ, 援助を要請 された人がしばしば経験する感情として,「心配だ」「悲 しくなる」「嫌気がさす」「軽荿する」「同情する」「関わ りたくない」「哀れに思う」「腹が立つ」の，8 つの感情 を選定し, それぞれの感情項目への回答を, 5 ポイント 尺度で求めた。また, 变数の操作か場面を変えることで 行われたため, その効果をチェックするための場面認知 項目（安定性の認知として，Aさんがてれまでに同じよ うなことを頼んできたか否か，原因の位置の認知として， そのような事態になったのはAさん自身のせいと思うか 否か, そして統制可能性の認知として, その事態を Aさ んが自力で乗り切ることができると思うか否か), 将来 $\mathrm{A}$ さんが再び同じような援助を求めてくる見込み，およ び援助の可能性について，5 ポイント尺度で回答を求め た。

\section{結果}

\section{操作のチェック}

変数操作の効果を検討するためにチェック項目への回 答を分析したところ, 原因の位置の認知には原因の位置 $(F=820.617, d f=1 / 202, p<.01)$ のほか代安定性 $(F=$ 287.311, $d f=1 / 202, p<.01)$ が, 安定性の認知には安
定性 $(F=393.849, d f=1 / 202, p<.01)$ のほかに原因の 位置 $(F=59.297, d f=1 / 202, p<.01)$ 乙統制可能性 $(F$ $=18.639, d f=1 / 202, p<.01)$ が，そして統制可能性の 認知には統制可能性 $(F=151.400, d f=1 / 202, p<.01)$ のほかに安定性 $(F=54.031, d f=1 / 202, p<.01)$ が, それぞれ有意な効果を及ぼしていた。れらの結果から， 認知された因果次元の完全な独立性について, 若干の検 討すべき問題を残すと考えられるが，原因の位置の認知 には原因の位置が, 安定性の認知には安定性が，そして 統制可能性の認知には統制可能性が，いずれ屯極めて強 い効果を及ぼしており，加えて，それぞれの原因の認知 に及ぼす当該の原因变数の効果を詳細に検討するために 他の因果次元について下位検定を行ったとてろ，操作変 数の効果はすべてに扔いて有効であるてとが確認された。 したがって, 変数の操作は一応妥当であったと考えられ る。そこで, これらの変数あるいはその認知を要因とし て Weiner モデルの検証と援助要請者之被要請者の間の 親密性の効果を明らかにするために，分散分析之重回帰 分析を行った。

\section{感情反応}

援助要請者への感情反応 (8 項目) の相関行列から, 主因子法によって共通因子を抽出した。さらにバリマッ クス法によって因子軸の直交回転を行い, 単純構造化を はかった。第 1 因子（固有値 $=3.541$, 寄与率 $=44.3 \%$ ) は, 軽荗する (.67), 嫌気がさす (.66), 関わりたくない (.63), 腹が立つ (.63) に高く負荷しており, 拒絶的感情 因子之名付けた。第 2 因子 (固有值 $=1.981$, 寄与率 $=$ 20.8\%) は，心配だ (.65), 哀れに思う (.54), 同情する (.53), 悲しくなる (.51) 亿高く負荷する因子であり，共 感的感情因子之名付けた。

拒絶的感情反応を分散分析した結果, 安定性 $(F=620$. $558, d f=1 / 202, p<.01)$, 原因の位置 $(F=163.538, d f=$ $1 / 202, p<.01)$, 統制可能性 $(F=137.698, d f=1 / 202$, $p<.01)$ ，抢よび親密性 $(F=298.610, d f=1 / 202, p<$ .01）の主効果が有意であった。すなわち，拒絶的感情 は，援助を必要とする原因が，安定的，内的，あるいは 自力で解決できると認知される時に，そして援助要請者 が被要請者と親しい関係にない時に, より一層強かった。 また, 安定性と親密性の間 $(F=28.900, d f=1 / 202, p<$ $.01)$ 之安定性と原因の位置の間 $(F=12.731, d f=1 / 202$, $p<.01)$ の交互作用がそれぞれ有意であった。そてで テューキー法による下位検定を行った結果, 前者の交互 作用では, 不安定条件で親密性の効果は有意でなかった が, 安定条件で親友よりも知人に対する拒絶的感情が有 意に強かった。また後者の交互作用では, 外的, 内的, 
実験社会心理学研究 第28巻 第 2 号

Table 1 感情反応, 将来の見込み, および援助可能性の平均値

\begin{tabular}{|c|c|c|c|c|}
\hline 条 件 従属変数 & 共感的 & $\begin{array}{l}\text { 拒絶的 } \\
\text { 感 情 }\end{array}$ & $\begin{array}{l}\text { 将来の } \\
\text { 見込み }\end{array}$ & 援 助 \\
\hline 親友 / 不安定 / 外的 / 統制不能 & 10.38 & 6.73 & 2.55 & 4.44 \\
\hline 親友 / 不安定 /外的 / 統制可能 & 9.47 & 8.23 & 2.89 & 3.95 \\
\hline 親友 /不安定 /内的 / 統制不能 & 9.34 & 7.80 & 2.94 & 4.18 \\
\hline 親友 /不安定 /内的 / 統制可能 & 9.12 & 8.99 & 3.20 & 3.85 \\
\hline 親友／安 定／外的／統制不能 & 10.45 & 8.48 & 3.55 & 4.18 \\
\hline 親友 /安 定 /外的 / 統制可能 & 10.34 & 9.85 & 3.83 & 3.84 \\
\hline 親友 /安 定 /内的 / 統制不能 & 10.43 & 10.21 & 4.14 & 3.92 \\
\hline 親友 /安 定 / 内的 / 統制可能 & 10.01 & 11.84 & 4.33 & 3.65 \\
\hline 知人 / 不安定 /外的 / 統制不能. & 10.86 & 7.26 & 2.63 & 4.37 \\
\hline 知人 / 不安定 / 外的 / 統制可能 & 9.37 & 9.05 & 3.01 & 3.84 \\
\hline 知人 / 不安定 /内的 / 統制不能 & 9.87 & 8.49 & 2.93 & 4.03 \\
\hline 知人 / 不安定 / 内的 / 統制可能 & 9.69 & 9.40 & 2.90 & 3.64 \\
\hline 知人 /安 定 /外的 / 統制不能 & 10.64 & 10.18 & 3.55 & 3.88 \\
\hline 知人 / 安 定 /外的 / 統制可能 & 10.33 & 11.13 & 3.62 & 3.61 \\
\hline 知人 /安 定 /内的 / 統制不能 & 10.20 & 12.24 & 4.01 & 3.50 \\
\hline 知人 / 安 定 /内的 / 統制可能 & 9.22 & 14.03 & 4.23 & 3.21 \\
\hline
\end{tabular}

いずれの条件であ安定性の効果は有意であったが，とり わけ内的条件において，いつむまじめに授業を受けてい る援助要請者よりあ, 普段からさぼりがちな要請者に対 して一層強い拒絶的感情を抱く傾向が見られた。

他方, 共感的感情反応の場合, 安定性 $(F=19.570, d f$ $=1 / 202, p<.01)$, 原因の位置 $(F=24.681, d f=1 / 202$, $p<.01)$ ，および統制可能性 $(F=33.807, d f=1 / 202$, $p<.01)$ の主効果と, 安定性と親密性の間 $(F=8.497$, $d f=1 / 202, p<.01)$ の交互作用が有意であった。また統 制可能性と親密性の間 $(F=2.674, d f=1 / 202, p<.10)$ で，交互作用の傾向が認められた。すなおち，援助要請 の原因が，安定，外的，あるいは自力で乗り切れないと 認知される時に, 被要請者の感情反応は要請者に対して 一層共感的であった。交互作用に関しては, 要請者が単 なる知人の場合, 安定性の効果は有意でないが，親友か ら要請された場合, 共感的感情は, まじめな相手に対し てよりも，さぼりがちな相手に対してむしろ強かった。 さらに相手が親友の時と違って知人の時, 自分で解決で きるのにしない相手よりも, 自分で解決できないために 援助を求めてきた相手に対する共感的感情が強かった。

\section{将来の再要請の見込み}

将来の援助再要請の見込みに関して分散分析した結果， 安定性 ( $F=1223.540, d f=1 / 202, p<.01)$, 原因の位 置 $(F=127.578, d f=1 / 202, p<.01)$, 統制可能性 $(F=$ $38.897, d f=1 / 202, p<.01)$, および親密性 $(F=11.935$, $d f=1 / 202, p<.01)$ の主効果と, 原因の位置と親密性 の間 ( $F=3.855, d f=1 / 202, p<.01)$ 之安定性之原因の 位置の間 $(F=10.369, d f=1 / 202, p<.01)$ の交互作用
がそれぞれ有意であった。すなわち，Aさんによる援助 要請の原因が安定的要因，Aさん自身の内的要因，ある いは統制可能な要因に帰属される時，そしてAさんが知 人であるよりあ親友である時, $\mathrm{A}$ さんが再び援助を求め てくる可能性は高いと推测された。原因の位置と親密性 の交互作用では，親友，知人，いずれの条件においても， 原因の位置の効果は有意であったが，相手が知人の場合， この傾向は特に強かった。被要請者は，法事で欠席した 相手よりあ，遊びのため欠席した相手が，今後再び援助 を求めてくる可能性が高いと推測していた。また安定性 之原因の位置の交互作用では, 安定, 不安定, いずれの 条件でも, 原因の位置の効果は有意であったが, 安定条 件において特に原因の位置の効果が大きかった。被要請 者は,さぼりがちな要請者が, 法事のために欠席する場 合よりも遊びのために欠席する場合, 将来同じ人が再び 助けを求めてくる可能性をより高く見積もっていた。

\section{援助可能性}

援助の可能性についての分析結果では, 安定性 $(F=$ $117.788, d f=1 / 202, p<.01)$, 原因の位置 $(F=83.604$, $d f=1 / 202, p<.01)$, 統制可能性 $(F=159.512, d f=1$ ) $202, p<.01)$ ，および親密性 $(F=202.040, d f=1 / 202$, $p<.01)$ の主効果が有意であった。すなわち, 援助要請 の原因が，不安定な要因，外的要因，および統制不可能 な要因に帰属される時にあるいは要請者と被要請者が親 密な関係にある時に, 被要請者が援助を提供する可能性 は一層高かった。有意な交互作用は, 安定性之親密性の 間 $(F=13.483, d f=1 / 202, p<.01)$ と原因の位置と親 密性の間 $(F=4.775, d f=1 / 202, p<.05)$ で認められた。 
西川・高木：援助要請の原因帰属と親密性が援助行動に及ぼす効果

Table 2 援助行動の重回帰分析結果

（標準偏回帰係数と重相関係数の2乗）

\begin{tabular}{|c|c|c|c|c|}
\hline 説明変数 & $\begin{array}{l}\text { 共感的 } \\
\text { 感 情 }\end{array}$ & $\begin{array}{l}\text { 拒絶的 } \\
\text { 感 情 }\end{array}$ & $\begin{array}{l}\text { 将来の } \\
\text { 見込み }\end{array}$ & $\begin{array}{l}\text { 援 助 } \\
\text { 可能性 }\end{array}$ \\
\hline 統制の位置 & -058 & -008 & 081 & -034 \\
\hline 統制可能性 & -087 & $175^{*}$ & $335^{* *}$ & 000 \\
\hline 安定性 & 089 & $260^{* *}$ & $205^{* *}$ & 000 \\
\hline 親密性 & 009 & $155^{*}$ & 034 & -056 \\
\hline 共感的感情 & & & & $170^{*}$ \\
\hline 拒絶的感情 & & & & $-460^{* *}$ \\
\hline 将来の見込み & & & & -080 \\
\hline $\mathrm{R}^{2}$ & 013 & $164^{* *}$ & $203^{* *}$ & 261 ** \\
\hline
\end{tabular}

安定性や原因の位置と親密性との交互作用では，相手が 知人, 親友のいずれの場合でも, 被要請者は, さぼりが ちな相手 (安定条件) や遊びが原因で援助を要請してき た相手（内的条件）よりも，いつもまじめに出席してい る相手 (不安定条件) やたまたま法事があったために援 助を要請してきた相手（外的条件）に対して，援助する 意志を一層強く持っており，とりわけての差は相手が単 なる知人の時に著しかった。

\section{パス分析による Weiner モデルの検討}

将来の再要請の見込みと感情反応とが，どの程度援助 要請の原因帰属と援助可能性（行動意図）との間を媒介
するかを検討するためにパス分析を行った。なおパス係 数は，それぞれの水準で行った重回帰分析から得らえた 標準偏回㷌係数である (Table 2)。

要請者への感情反応のうち, 拒絶的感情には安定性 (.260), 統制可能性 (.175), および援助要請者と被要請 者との間の親密性 $(.155)$ が，比較的強い直接効果を及 ぼしていた。とてろが，共感的感情因子に関しては，有 意な効果を与える要因がなかった。将来同じ相手が再び 援助を求めてくる見込みに対して，援助要請原因の統制 可能性 (.335) と安定性 (.205) が比較的強い影響力を及 ぼしていた。

援助可能性に対しては, 拒絶的感情 (-.460) がとりわ け強い直接効果を及ぼしており，てれに次いで共感的感 情 (.170) あ援助可能性を規定していたが, 因果の 3 次元 と親密性の直接効果はいずれも有意でなかった (Fig.1).

考察

援助を要請された者の感情反応を因子分析した結果, 要請者住対する拒絶的感情因子之共感的感情因子が抽出 されたが，乙れら2因子は，Meyerら (1980) が明らか にした, 被要請者の要請者に対する怒りの感情と共感的 感情に対応していると考えられる。すなわち，援助を求 められた者は，相手の困難な事情について心配し，哀れ さを感じると同時に，相手に軽茂や嫌気を感じ，できれ
独立変数

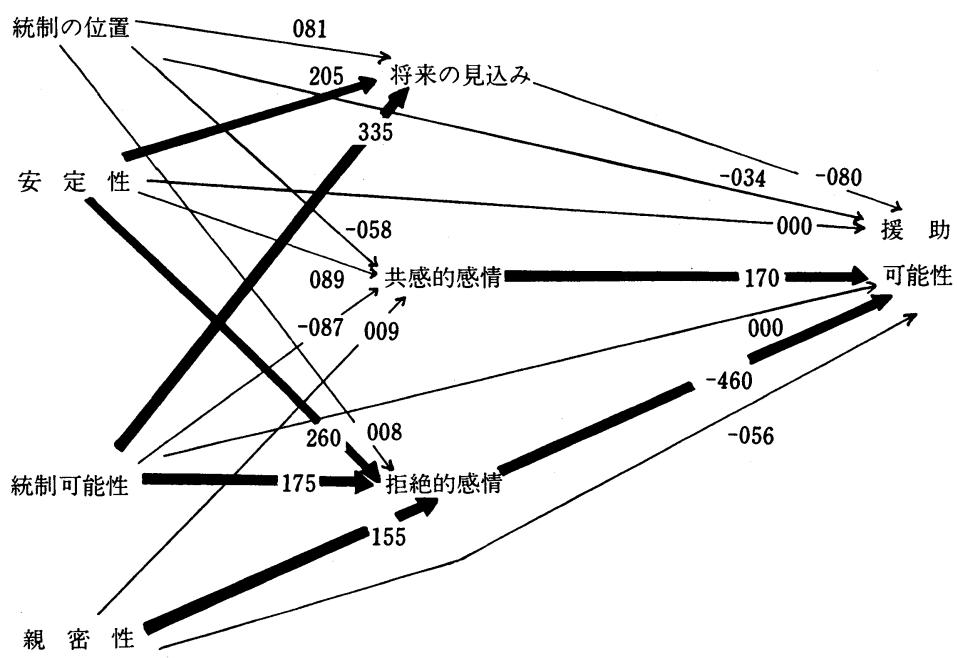

註 $太$ 線 $\cdots \mathrm{p}<.05$ 細線 $\cdots \mathrm{ns}$

Fig. 1 援助行動の因果関係図 
ば関わりたくないと思うょうである。

被要請者の感情反応を分散分析した結果, 拒絶的感情 では, 安定性, 原因の位置, および統制可能性の主効 果が有意であり, 仮説 1 (a) が支持された。Meyer ら （1980）は, 怒りの感情に及ぼす安定性と統制可能性の 主効果を明らかにしたが, 本研究は, 乙れらに加えて拒 絶的感情に及ぼす原因の位置の効果を見出した。拒絶的 感情についての交互作用は, 安定性之親密性, および安 定性と原因の位置との間で有意であった。いつ屯真面目 に授業に出席している要請者に対して, その人が知人で あろうと親友であろうと, 拒絶的感情はさほど強くはな かった。しかし, 日でろ授業に出席しない人から援助を 要請され，しかもその相手が 1,2 度しか話をしたてと のない知人の場合, 被要請者はとりわけ強い拒絶的感情 を抱いた。被要請者は, 親密な交流の無い相手からの突 然の援助要請を, 相手が一時の苦況を脱するための便宜 的手段として解釈し, 対人関係を道具的にとらえる相手 に対して強い拒絶的感情を持ったあの之思われる。また， 普段から真面目に授業を受けない人が遊びに出かけるた めに欠席した場合, 被要請者の拒絶的感情がとりわけ強 かった。被要請者は, 要請者が本人の怠惰な性格のため に苦況に陥ったにもかかわらず，その困難な状況の解決 を他人に要請する態度に対して, 強い拒絶的感情を抱い たと思われる。

援助要請者への共感的感情には, 安定性, 原因の位置, および統制可能性の主効果が有意であった。 Meyer ら （1980）は，共感的感情に及ぼす統制可能性の主効果の みを明らかにしたが, 本研究は帰属の 3 次元がいずれす 要請者への共感的感情を規定することを明らかにした。 ただし, 共感的感情に及ぼす安定性の効果は仮説された 方向とは逆であり, 被要請者はむしろいつむさぼりがち な要請者に一層強い共感的感情を抱いていた。したがっ て, 仮説 1 (b) のうち, 原因の位置と統制可能性の効果 は検証されたが, 安定性の仮説された効果は検証されな かった。被要請者は, 普段真面目に授業に出席している 要請者よりも, 常々さぼりがちな要請者に対してより強 い共感的感情を抱いていたが，乙てでの共感的感情は, 学生の本分である授業への出席をいつあさぼるような学 生を哀れに思い，そのような学生が将来招く重大な事態 を心配するといった感情で特徴づけられる。すなわち, 不安定条件の被要請者は，いつも真面目に授業に取り組 んでいる相手が過去にてのような苦況を招いたてとはあ まりなく, 今後の学習への取り組みについてもさほど心 配することはないと思ったのであろう。他方, 安定条件 の被要請者は, 要請者の今後の成果を心配し, 相手を哀
れに感じたと思われる。

Meyer ら (1980) は, 帰属 3 次元の中であ統制可能性 次元が感情反応を最も強く規定すると主張したが, 本研 究は, 統制可能性次元のほか心安定性次元と原因の位置 次元も拒絶的感情と共感的感情とを規定するととを明ら かにした。したがって, 本研究は, 因果帰属の 3 次元が 感情反応に影響を及ぼすという Weiner モデルをより強 く支持したと考える。

将来の援助再要請の見込みについては, 帰属の 3 次元 の主効果が有意であり, 仮説 2 が検証された。将来再び 同じ援助が要請されるかどうかは, 第 1 亿その要請が安 定した原因によって引き起てされたか否かによって規定 されると考えられてきたが (Weiner, 1979), 本研究は, 将来の見込みが他の 2 つの帰属次元によっても規定され るととを示した。援助要請者自身が, 困難な状況に陥る ことを予測しながらあ, 安易に苦況に立つことを選び, さらにその状況を深刻なものとは考えず，また自分で解 決できるにあかかわらず, 援助をたやすく他人に要請す る場合, 被要請者は要請者が将来再び同じ援助を要請す ると推測したのであろう。交互作用に関して, Meyer ら の結果では, 安定, 外的条件で将来の援助再要請の見込 みが最む高かったが, 本研究では, 援助要請者が急惰な 性格（安定条件）で，しかも自ら困難な状況を招く（内 的条件）場合に, 将来再び援助要請が行われる見込みが 最む高く評定された。援助要請者は怠惰な性格であり, かつ遊びのために講義をさぼった結果援助を必要とした のならば, 要請者は過去にあ同じ理由でたびたび困難な 事態を招いてきたと思われる。したがって，被要請者は， 要請者が今後む同じ理由で援助を求める見込みが高いと 推測したのであろう。

援助可能性についても, 因果帰属の 3 次元の主効果が 有意であった。Ickes \& Kidd (1976) は原因の位置より あ統制可能性が援助判断をより強く規定すると論じ, ま た Meyer らむ統制可能性と安定性の主効果を検出し, Ickes らの主張を支持した。しかし, 本研究はそれらに 加えて原因の位置む援助判断を規定することを明らかに した。Ickesら (1976)や Meyer ら (1980)は, 初期の 研究 (例えば, Schopler \& Matthews, 1965) が, 原因 の位置次元と統制可能性次元を混同して打り, 本来は, 統制可能性次元が原因の位置次元よりも援助判断をより 強く規定すると述べてきた。しかし本研究の結果では， 独自に操作した統制可能性と原因の位置とがそれぞれに 援助可能性に強い影響を及ぼしていた。むちろん，てれ らの結果から原因の位置も援助可能性㳰響を与えうる のだと直ぐさま結論づけることはできないかもしれない。 
そこで今後は従来の研究で設定された状況とての研究の 状況の特徵を詳細に分析するととあに, 状況の特徵に応 じて場面を組織的に設定して，その普遍性を明らかにす る必要があろう。

援助要請者と被要請者の親密性は, 拒絶的感情に有意 な効果を及ぼしており，仮説 4 (a) が検証された。同じ 援助を求められても，相手が非常に親しい人の場合より あ相手が単なる知人でしかない場合に, 被要請者は一層 強い怒りや嫌気を感じていた。援助要請者之被要請者と の間に友好関係が結ばれている場合, 相手の依存的態度 に対する拒絶的感情は割り引かれるようである。他方, 共感的感情に及ぼす親密性の主効果は有意ではなく, 仮 説 4 (b) は支持されなかったが, 安定性と親密性との交 互作用が有意であった。要請者が単なる知人の場合, 相 手への心配や哀れみは真面目か不真面目かによって相違 しないが, 親友の場合, さぼりがちな相手に対してその ような感情を一層強く持った。乙の結果は, 本研究で見 出された共感的感情因子が援助要請者を哀れに感じ, 彼 の将来を心配するといった, 悲哀的感情によってより強 く特徵づけられることを示している。

援助再要請に対する見込みに及ぼす親密性の主効果は 有意であり，仮説 4 (c) が検証された。援助要請者が知 人ではなく親友の場合, 被要請者が今後屯要請者との親 しい関係の継続を予測した結果, 相手が将来再び要請し てくる見込みをより高く判断したのであろう。

親密性は援助可能性にも有意な主効果を及ぼしており, 仮説 4 (d) が検証された。乙の結果は, 援助者之被援助 者の親密度が高ければ高いほど, より援助が多く行われ たという小嶋（1983）の結果と一致している。被要請者 は, 親友から援助を要請された場合, 知人から要請され た場合よりも, 相手が将来再び援助を求めてくるてとを 予測しながらあ拒絶的感情をあまり抱かず, 結果的に援 助を申し出る傾向にあると考えられる。

Weiner モデルでは, 援助要請の原因帰属が，まず被 要請者の感情と, 今後その要請者が再び助けを求める見 込みとに影響を及ぼし，その感情と見込みとが，次に援 助判断を規定する。Meyer ら (1980) あまた, 因果次元 にそった㷌属が，感情・見込みを経て援助判断に影響を 及ぼす間接効果のほかに, 援助判断への直接効果を持つ 之考えて，パス分析を行っている。そてで次に，因果の 3 次元之援助可能性との間で感情反応之将来再要請の見 込みが果たす媒介効果を検討するために，パス分析の結 果 (Fig. 1, Table 2) を考察する。

援助要請者汇対する被要請者の感情反応をパス分析け 結果から見ると，拒絶的感情に対しては，原因の位置の
効果は見出せなかったものの, 安定性と統制可能性が比 較的強い効果を及ぼて扔り，乙の結果むまた，分散分 析の結果之同様に，ほぼ仮説 1 (a) を支持した。Meyer らのパス分析の結果は, 統制可能性のみが怒りの感情を 強く規定するととを明らかにしたが, 我々の結果は, 統 制可能性にす増して, 安定性が強い直接効果を及ぼすて とを示している。てれは, 本研究で安定した原因として 設定した要請者の怠惰な性格特性が, 被要請者の要請者 に対する拒絶的感情をいっそう強く喚起したためと考え られる。

共感的感情を規定すると考えられた要因の中には, 重 大な影響を与える変数は見当たらず，パス分析の結果は 仮説 1 (b) を積極的には支持しなかった。乙の研究で設 定された，人から援助を要請されるという状況では，あ ともと被要請者の要請者に対する共感的感情が喚起され にくく, 他方, 拒絶的感情がかなり強く喚起されると考 えられる。また，既に述べたように，本研究での共感的 感情は，回避できずに苦況に立った人への同情的共感亡 ともに，回避できたにあかかわらず，敢えて苦況を招い た人への悲哀的共感をも強く含んでいた。したがって, 分散分析とパス分析の結果から, 仮説 1 (b) で予測した ような因果次元と共感的感情との間の関係性を, 明確に 検証することはできなかったと考えられる。今後は，共 感的感情を捉えるための項目を十分に検討し，被要請者 が要請者に抱く肯定的感情の構造を明らかにする必要が あるだろう。

Weiner ら (1979) は, 将来の援助再要請の見込みが安 定性によって規定されると考えているが， Meyer らの 結果では, 将来の見込みは安定性のみならず, いずれの 帰属次元と屯深く関連していなかった。しかし, 本研究 は, 将来の再要請の見込みの評定が, 安定性に加えて統 制可能性によっても強く影響されるてとを示した。つま り, 相手が援助を要請するに至った原因を, 安定した要 因や統制できる要因に帰属すれば, 被要請者は, 要請者 が近い将来, 再び同じ理由で援助を求めてくる見込みが 高いと判断するのである。乙の結果は仮説 2 を支持して おり, Weiner モデルで仮説された将来の達成行動につ いての信念と帰属次元との関係性を検証した。

援助可能性に及ぼすそれぞれの変数の効果を見れば, 拒絶的感情が援助可能性に対して最む強い効果を及ぼし, 次いで共感的感情が援助可能性を規定していた。ての結 果は仮説 3 (a)（b) を支持している。援助要請者に対し て, 共感的感情をあまり抱かず, むしろ拒絶的感情を強 く抱いている人は, 実際にその相手に援助の手を差し述 べるてとがないだろう，と判断するのである。 Meyer 
らもまた, 援助者に対する怒りの感情が援助判断を最も 強く規定するてとを明らかにしており, 我々の結果は彼 らの結果と一致している。しかしながら, Meyer らと 同じく, 本研究でも援助可能性に及ぼす将来の再要請の 見込みの効果を見出すことはできず，仮説 3 (c) は検証 できなかった。援助するか否かといった行動の意思決定 では, Weiner らが想定した課題達成行動と異なり, 拒 絶的あるいは共感的感情が将来の援助再要請の見込みよ りあはるかに強い影響を及ぼしているのである。

被要請者の感情反応に影響を及ぼすと考えられる親密 性は，拒絶的感情に対して有意な直接効果を与えており， 仮説 4 (a) は支持された。しかし，共感的感情への親密 性の直接効果は有意でなく, 仮説 4 (b) は支持されなか った。また, 親密性が将来の援助再要請の見込み, およ び援助可能性に及ぼす直接効果む有意ではなく, 仮説 4 （c）（d）は支持されなかった。乙れらの結果から，親密 性は援助要請者への拒絶的感情を媒介变数として, 援助 可能性に影響を及ぼすことが考えられる。

以上の諸結果は, 感情反応が因果次元の達成行動に及 ぼす効果を媒介するという，Weiner の帰属モデルを支 持している。すなわち将来の援助再要請の見込みは安定 性によってより強く規定されると Weiner は述べている が, 我々の結果では, さらに統制可能性も将来の援助再 要請の見込みを強く規定していた。援助要請者への拒絶 的感情には安定性と統制可能性とが効果を及ぼしていた。 援助可能性に対しては, どの因果次元もそれほど強い直 接効果を持たないが, 拒絶的感情と共感的感情の感情反 応が強い媒介的影響を及ぼしていた。

しかしながら, 因果 3 次元と共感的感情反応との関係 や援助可能性に対する将来の援助再要請の見込みの効果 は確証されなかった。また，それぞれの因果次元は，場 面の一部を変えることによって，独自に操作されたが， 被験者がこれらの次元を完全に独立したものとして認知 したとも言い難い。したがって，本研究の結果は因果の 3 次元と感情や援助可能性との関係を一応捉えてはい るあのの，それらを十分に解明したと結論づけることは できない。Weiner (1986) は，他者による統制の可能性 を想定するてとによって因果 3 次元の独立性を一層高め ることができると提案している。Weiner モデルの援助 行動への適用可能性を詳細に検討するためには，乙の Weiner の提案を考慮しつつ, 場面の設定や実験の実施 方法をさらに工夫する必要がある。今後は, 感情, 特に 親密性と微妙な関係を示した共感的感情の構造を再検討 したうえで, 因果帰属の 3 次元が相互に独立になるよう な場面を設定し, 因果帰属と感情反応，および援助の可
能性との関係をさらに究明しなければならないと考える。

\section{引用 文 献}

Barnes, R.D., Ickes, W. \& Kidd, R.F. 1979 Effects of the perceived intentionality and stability of another's dependency on helping behavior. Personality and Social Psychology Bulletin, 5, 367-372.

Berkowitz, L. 1969 Resistance to improper dependency relationship. Journal of Experimental Social Psychology, 5, 283-294.

Ickes, J. \& Kidd, R. F. 1976 An attrirbutional analysis of helping behavior. In J. H. Harvey, W. J. Ickes \& R. F. Kidd (Eds.), New directions in attribution research (Vol. 1). Hillsdale, N. J.: Erlbaum.

小嶋正敏 1983 援助行動の生起機制に関する㷌属理論 的分析; 原因帰属, 感情, 親交度の効果, 早稲田 大学心理学年報第15巻別冊, 31-42.

Meyer, J. P. \& Mulherin, A. 1980 From attribution to helping: An analysis of the mediating effects of affect and expectancy. Journal of Personality and Social Psychology, 39, 201-210.

Piliavin, I. M., Rodin, J. \& Piliavin, J. A. 1969 Good samaritanism: An underground phenomenon? Journal of Personality and Social Psychology, 13, 289-299.

Rosenbaum, R. M. 1973 Dimensional analysis of the perceived causes of success and failure. Dissertation Abstracts International, 33, 5040B.

Schopler, J. \& Matthews, M.W. 1965 The influence of the perceived causal locus of partner's dependence on the use of interpersonal power. Journal of Personality and Social Psychology, 2, 609-612.

Schwartz, S. H. \& Fleishman, J. A. 1978 Personal norms and the mediation of legitimacy effects on helping. Social Psychology, 41, 306-315.

Weiner, B. 1972 Theories of motivation: From mechanism to cognition. Chicago: Rand McNally.

Weiner, B. 1979 A theory of motivation for some classroom experiences. Journal of Educational Psychology, 71, 3-25.

Weiner, B. 1980 A cognitive (attribution) - emotion - action model of otivated behavior: An analysis of judgments of help-giving, Journal of Personality and Social Psycho$\log y, 39,186-200$.

Weiner, B. 1986 An attribution theory of achieve- 
ment motivation and emotion. Psychological Review, 92, 548-573.

Weiner, B., Russell, D. \& Lerman, D. 1979 The cognitive-emotion process in achievement- related contexts. Journal of Personality

and Social Psychology, 37, 1211-1220.

-1987年 6 月 11 日 受稿, 1988年 6 月 18 日 受理一

\section{EFFECTS OF THE ATTRIBUTION OF NEED FOR HELP AND THE RELATIONSHIP BETWEEN THE POTENTIAL HELPER AND THE PERSON IN NEED ON HELPING BEHAVIOR}

\author{
MASAYUKI NishiKaWA \\ (Osaka University of Education)
}

\author{
Osamu TAKagI \\ (Kansai University)
}

\begin{abstract}
The purpose of the present study was to explore the applicability of Weiner's attributional model of motivation to the study on helping behavior. It was predicted that willingness to help the person in need would be influenced by the attributed causes of the need and that the relationship between the attribution and helping behavior would be mediated by affective reactions to the request and expectancy of future need.

Two hundreds and four subjects were asked to rate the likelihood that they would lend class notes to an acquaintance or to an intimate friend in each of eight conditions under which causality varied along three dimensions: stability, locus,
\end{abstract}

and controllability. They also rated their emotional reactions on 8 scales and estimated the likelihood that the person would require aid again in the future.

Analysis of variance revealed that both the willingness to help and affects were influenced by all three causal dimensions and the intimacy of relationship. Consistent with the mediation hypothesis, a path analysis revealed that controllability and stability of cause had great influences on negative affect, and the intention of help were influenced by affective reactions to the request. Contrary to expectation, the predicted mediational effect of expectancy of future need was not. observed.

Key words: Helping behavior, Prosocial behavior, Attribution of need for help, Affect to helping request, Intention of help-giving, Intimacy of relationship 